\title{
Om Grundtvigs tidsopfattelse
}

\author{
Nogle idehistoriske bemærkninger \\ af William Michelsen
}

„... hvor Kierkegaard vil holde mennesket fast på samtiden eller øjeblikket - inddrager Grundtvig (beroligende) den fremtid, som endegyldigt skal føre kraftbeviset". Således skriver P.G. Lindhardt i sin bog Konfrontation (1974) s. 217.

De citerede ord vil formentlig normalt blive opfattet på følgende måde. Kristendommen (og om den drejer hele sætningen sig) er en tro, hvilket vil sige en ubeviselig påstand. Dette fastholder Kierkegaard, idet han kræver af sine medmennesker, at de (hvis de vil være eller kalde sig kristne) i ethvert øjeblik forholder sig til det evige (Kristus) og derved ganske konkret er samtidige (med Jesus og hans evangelium). - Grundtvig derimod beroliger sine medmennesker ved at henvise dem til en fremtid, som er ganske ubekendt, og i hvilken man derfor sagtens kan love dem "guld og grønne skove“ (en evig salighed, hvori de traditionelle forestillinger om et evigt liv efter døden vil blive virkelighed). At Kierkegaard har ret, mens Grundtvig dels henviser til en udvikling, der aldeles ikke har opfyldt hans forventninger (om den kristne tros fremgang), dels giver sine medmennesker "luftsteg og lamperøg“ eller „Veksler på Evigheden“ (tomme løfter om sjælens udødelighed) forekommer ubestrideligt. For sådan tænker både de lærde og menigmand nu, og det gjorde både lærde og menigmand også i forrige århundrede.

Der er imidlertid hos Kierkegaard og Grundtvig tale om to helt forskellige opfattelser af tid og evighed, som her bliver sammenblandet. $\mathrm{Og}$ menigmands opfattelse ligner $\mathrm{i}$ virkeligheden mere Grundtvigs end Kierkegaards. Men resultatet af sammenblandingen bliver, at den, der ikke (som de lærde) er i stand til at følge Kierkegaards opfattelse, så at sige nødes til at opfatte den kristne tale om et evigt liv som "Løgn og forbandet Digt". - Der er i 
denne situation god grund til at gøre nærmere rede for de to tidsopfattelser, der ønskes konfronteret i Lindhardts citerede ord.

Kierkegaards tidsopfattelse har bl. a. Johannes Sløk gjort rede for i sin bog "Die Anthropologie Kierkegaards" (Kbh. 1954) kapitel 1 § („Zeit, Ewigkeit. Augenblick“). - Kierkegaard går ud fra Kants opfattelse af tiden som "apriorisk kategori“, dvs. en af de forestillinger i den menneskelige fornuft, der er forudsætning for, at vi overhovedet kan forstå det, der foregår i verden (naturen og menneskelivet eller historien). Ifølge denne tidsopfattelse er tiden uendelig; tidsforestillingen indebærer, at den ene begivenhed følger efter den anden og altså ikke kan ombyttes, (en irreversibel succession) og intet andet. - Når man går ud fra denne tidsopfattelse, bliver det meningsløst at tale om tidens begyndelse og ende, og evighed må da opfattes som noget andet end det, der går forud for og følger efter tiden. Evighed kommer da til at betegne noget andet end det, vi normalt kan forstå mht. begivenhederne $\mathrm{i}$ verden (naturen og menneskelivet - historien). Øjeblikket eller det narvarende (samtiden, det samtidige) bliver det afgørende skel mellem fortid og fremtid og det eneste punkt, på hvilket mennesket er i stand til at træde $\mathrm{i}$ forbindelse med det evige, nemlig i et valg eller en beslutning; og dette anses for at karakterisere mennesket $\mathrm{i}$ modsætning til alle andre naturvæsener. I ojeblikket ligger menneskets frihed. - Denne tidsopfattelse er som sagt ikke speciel for Kierkegaard; han delte den med Kant og den tyske filosofi efter Kant; den fremhævedes i dansk filosofi særlig af J. L. Heiberg, der havde lært den af Hegel. - Når Kierkegaard hævder denne tidsopfattelse, gør han det, fordi samtiden gjorde det - vel at mærke den filosoferende samtid, herunder samtidens teologer. Men Kierkegaard gør det i den stik modsatte hensigt af J.L. Heibergs: Kierkegaard vilde tvinge samtidens mennesker til et spring $u d$ af et metafysisk system, hvori de mente at kunne betragte tilværelsen „under evighedens synspunkt“. Heiberg havde $\mathrm{i}$ sin afhandling „Om den menneskelige Frihed“ (1824) netop villet tvinge sine læsere til et spring ind $i$ dette system - og beroligede dem med, at det jo kun var metafysik. Den sædvanlige forestilling om det evige liv forsvandt jo nemlig for menigmand, hvis han skulde komme til at læse Heibergs afhandling!

Kierkegaard beroligede ikke sine læsere. Han stillede dem med 
god grund over for det krav, der ligger i menneskets frihed; kravet om et valg, en beslutning, en handling. Et krav, der ligger i tidsopfattelsen, explicit hos Kierkegaard, latent hos Kant. Et krav, der var og er forståeligt for ethvert menneske, fordi der er noget sandt i denne tidsopfattelse, dvs. fordi den stemmer overens med vor opfattelse af virkeligheden i dette punkt: det er ikke muligt for os at foretage noget valg mht. fortiden; og mht. fremtiden kan vi kun træffe noget valg $i$ dette øjeblik; enhver udskydelse af valg eller beslutning betyder, at situationen vil være en anden, når valget træffes. At undlade at vælge $\mathrm{i}$ dette øjeblik er også et valg: nemlig valget at underkaste sig nødvendigheden i stedet for at gribe muligheden.

Men denne - eksistentielle - tolkning af Kants tidsopfattelse er så at sige Kierkegaards opdagelse og ganske forskellig fra den - systematiske - tolkning, der var (og tildels stadig er) den almindelige: nemlig at det er os mennesker muligt at overskue begivenhederne i verden (ikke blot i naturen, men også i menneskelivet, i historien) „fra evighedens synspunkt" og - forudberegne dem! Vi foretager prognoser mht. befolkningstal og økonomiske forhold ligesom man forlængst har forudberegnet planeternes stilling og solformørkelser, skønt vi dog godt véd, at vi selv kan vælge at begrænse de forhold i menneskelivet, som bestemmer både det enkelte menneskes liv og de historiske begivenheder ... at vi netop derfor $i k k e$ er i stand til at overskue fremtiden. Vi har mulighed for at modvirke de farer vi ser true os.

Hvordan var nu Grundtvigs tidsopfattelse? - Det væsentligste i den var, at han modsat Kant og Kierkegaard opfattede tiden som begranset - og evigheden som ubegrænset - og at han ( $\mathrm{fx}$. i det vers, han i 1804 satte på forsiden af sin dagbog) netop heri så den afgørende ansporing for mennesket til handling. - Tidens begrænsning var for ham en fundamental erfaring, for hans vedkommende formentlig bl. a. erhvervet ved to ældre brødres og en yngre søsters død, men jo overhovedet en almen menneskelig erfaring. Det er nok muligt, at Grundtvig i en periode som ung fandt det muligt at tilegne sig en intellektuel anskuelse af naturen og menneskelivet og dermed se også tiden fra evighedens synspunkt. Men selv i den mytologiske betragtning af menneskelivet, han fandt $\mathrm{i}$ de nordiske eddadigte, forekom tidens begyndelse og ende som udtryk for selvfølgelige begreber, ja, begivenheder. 
Grundtvig foretog altså ikke noget spring ind i en metafysisk spekulation, der hævede ham over tiden - omend han, som det hedder $\mathrm{i}$ en dagbogsoptegnelse fra Langelandsårene "forlod Livet med Schelling $\mathrm{i}$ hans Bruno". Han omformede $\mathrm{i}$ stedet den idealistiske filosofi til mytologiske billeder (N. M. 1808), som han siden kunne frigøre sig fra som et historisk bestemt aftryk af de nordiske folks livsanskuelse (tydeligt udtalt i N.M. 1832). Da han (i en optegnelse fra 1813) stillede sig selv over for det spørgsmål, om mennesket var afhængigt eller uafhængigt af tiden, måtte han svare: „afhængigt". Har Grundtvig nogensinde foretaget noget „spring“ i sin tænkning, må det være dette spring ud af den idealistiske filosofi, som kan ses i de forelæsningsudkast fra 1813, han gav overskriften „Om Menneskets Vilkaar“ (trykt af Hal Koch i Værker i Udvalg II, spec. s. 265-269 jf. min omtale i Nordisk tidskrift 1946, spec. s. 388-90).

Man kan ikke hos Grundtvig som hos Kierkegaard tale om nogen banebrydende filosofisk opdagelse, men nok om en ganske tilsvarende protest mod idealismen, nemlig en energisk hævdelse af modsigelsens grundsætning - ikke blot som en tankelov og som et apologetisk våben mod kristendommens kritikere, men også som en protest mod den i samtiden almindelige opfattelse, at der må være noget sandt i enhver af fornuftige mennesker antagen påstand (hvad H. C. Ørsted direkte hævdede) - at ren løgn m. a. o. er noget, der ikke forekommer hos fornuftige mennesker! Denne optimistiske opfattelse var Grundtvig en vederstyggelighed.

For Grundtvig var f. ex. den opfattelse, at tiden ikke var nogen virkelig ting, men blot en forestilling i den menneskelige fornuft, simpelthen løgn. Den idealistiske filosofi sammenblandede tid og evighed. Den kristne tro og det evige liv erstattedes af en uholdbar metafysik, hvilket også Kierkegaard protesterede imod. Men Grundtvigs protest mod denne sammenblanding af tro og filosofi fik en anden form end Kierkegaards protest, fordi Grundtvigs tidsopfattelse var Bibelens og nærmere menigmands. Hvor Kierkegaard akcepterede Kants metafysiske tidsbegreb, fastholdt Grundtvig det førkantiske. Grundtvigs henvisning til fremtiden er altså netop en fastholdelse af begrebet tro i dets egentlige betydning: en tillidsfuld antagelse af en ubeviselig påstand.

I realiteten er der næppe nogen virkelig forskel mellem Kierke- 
gaards og Grundtvigs trosbegreber. De er begge rettet imod den idealistiske filosofis metafysiske systemer, anvendt som religiøse surrogater. Det er urimeligt at føre dem i marken imod hinanden, fordi de går ud fra to forskellige tidsopfattelser. Kierkegaard opererede med sin samtids filosofiske tidsopfattelse, Grundtvig afviste den. - Resultatet er blevet, at man for at være kristen i eksistentiel forstand nu så at sige tvinges til at akceptere en tidsopfattelse, som strider imod den for menigmand normale, som genfindes i Bibelen. Dét er at gøre kristendom til et spørgsmål om evnen til at sætte sig ind i en kunstig metafysisk tankegang, som ikke blot Kierkegaard, men også kristendommen protesterer imod.

Der er ikke noget $\mathrm{i}$ vejen for at gå ind på det værdifulde sandhedsmoment, som ligger i Kierkegaards tidsopfattelse, uden at akceptere den urimelighed, at tiden er uendelig og en blot hjælpeforestilling i den menneskelige fornuft. Det forholder sig tværtimod sådan, at øjeblikket, valget, beslutningen, handlingen er naturlige begreber $\mathrm{i}$ den naturlige tidsopfattelse, der sætter øjeblikket som skel mellem fortid og fremtid. Men det er urimeligt at opfatte Grundtvigs tidsopfattelse som en beroligende sovepude, når fremtiden for ham tværtimod er alle tings prøve - også den kristne tros sandhedsprøve.

At det endegyldige kraftbevis på kristendommens sandhed først vil komme ved tidens ende, vil naturligvis kun kunne opfattes som tomme løfter af den, der kræver bevis og kræver det nu. Men gør man det, så véd man ikke, hvad tro er.

Grundtvigs tidsopfattelse er oprindelig endimensional: tiden opfattes som et begrænset liniestykke af en ubegrænset linie, som kaldes evighed. Der er for Grundtvig ingen forskel mellem evighed og uendelighed - hvad der derimod er både for Kierkegaard og de filosoffer, hvis tankegang og dermed tidsopfattelse han følger, ikke blot Kant, men også Platon. De opfatter evigheden som en metafysisk ikke-tid, dvs. en spekulativ afstand, fra hvilken det er muligt (hvad der ikke er muligt i det praktiske liv) at overskue timeligheden (fortid, nutid, fremtid), som om det var muligt at hæve sig over tiden og blot respektere den bevagelse, den udtrykker.

Tiden er en bevagelse, der ikke kan gøres om igen. Derom kan formentlig alle være enige. En tilbagegang i tiden kan kun gøres i erindringen eller ved hjælp af historiske dokumenter. Fortiden 
kan tildels rekonstrueres - men ikke tilintetgøres og gøres om igen. Man kan lade, som om fortiden ikke eksisterede; men dens eftervirkninger eksisterer $\mathrm{i}$ nutiden og kan ikke ses bort fra, uden at man vender ryggen til en del af virkeligheden. Den, der vil kende virkeligheden, må altså tage fortiden med - og kan ikke lade, som om han kender fremtiden.

Fremtiden er en fortsættelse af den bevægelse, som vi kender fra fortiden. Vi kan til en vis grad forudberegne naturbegivenheder i fremtiden, fordi vi kender de naturlove, hvorefter de hidtil har fundet sted. Men vi kan ikke forudberegne alt. Vi kan - men kunde ikke på Grundtvigs tid - konstruere våben, der kan tilintetgøre den menneskelige kultur over det meste af jorden. Men vi kan også lade være. $\mathrm{Og}$ selv om vi konstruerer dem, kan vi lade være at bruge dem. Men vi kan ikke forudberegne, om vi vil konstruere og bruge dem eller ej. Vi er stillet over for et valg, som gør os ansvarlige for klodens fremtid. $\mathrm{Og}$ valget skal gøres i øjeblikket. Valget er politisk, men tillige eksistentielt for hvert enkelt individ, der har nogen stemme $\mathrm{i}$ dette valg. Valget indgår i den tid, som er en bevægelse, der ikke kan gøres om. - Valgets følger rammer ikke så meget os, som vore efterkommere.

Om disse ting antager jeg ikke der kan være nogen uenighed. For Grundtvig og Kierkegaard var der formentlig heller ingen uenighed om det principielle heri, men de teknologiske og politiske konsekvenser, vi nu kender, vilde have forekommet dem fantastiske. For dem drejer sagen sig om de religiøse og videnskabelige konsekvenser af tidsopfattelsen: hvad skal der forstås ved "det evige Liv“ i kristen betydning? - Er det videnskabeligt (videnskabsteoretisk, filosofisk) muligt at antage, at verden er blevet til og vil gå under? - Er det m. a. o. muligt at akceptere tiden som en begranset bevægelse i én retning, mens evigheden er en ubegranset bevægelse, der muligvis kan tage flere retninger? Eller er det logisk mere akceptabelt at antage, at tiden er en hjælpeforestilling i den menneskelige hjerne til strukturering af de forløb, vi oplever gennem sanserne? - Men hvad er i så fald evigheden? - Det var den tyske idealismes problemer.

Men for Grundtvig drejede sagen sig ikke om, hvilken tidsopfattelse der var logisk mest håndterlig eller bedst egnet til at modarbejde en skeptisk filosofi (Humes), men om hvorvidt tiden var afhangig af mennesket eller mennesket afhængig af tiden. 
Han svarede (i oktober 1813), at mennesket var afhængig af tiden. Dermed havde han udelukket en tidsopfattelse, der gjorde tiden til en apriorisk forestilling (Kant), og bundet sig til den før-kantiske opfattelse, han bl. a. fandt i Bibelen.

For Kierkegaard var problemet et andet, nemlig hvordan det var muligt at være en kristen, når samtiden havde valgt Kants tidsopfattelse, Hegel videreførte den og Heiberg indførte Hegels filosofi i dansk litteratur. - Hvad var da evigheden? Og på hvilken måde var det muligt for det $\mathrm{i}$ tiden eksisterende menneske at træde i virkelig (ikke blot metafysisk, spekulativ) forbindelse med evigheden? - Hvilken rolle spillede da øjeblikket (som Heiberg havde karakteriseret ved vilkårlighed og tilfældighed)? - Kierkegaards svar var: kun i øjeblikket træder mennesket $\mathrm{i}$ forbindelse med evigheden, ved et valg. Kun hvis Gud træder ind i tiden og mennesket bliver samtidigt med ham, kan det blive kristent.

Kierkegaards tidsopfattelse bliver altså todimensional og transcendental: evigheden er en anden tilværelse („tid“) end timeligheden og griber kun ind i timeligheden på enkelte punkter, nemlig hvor mennesket $\mathrm{i}$ øjeblikket ved et valg forholder sig frit til det evige. $O g$ når mennesket ikke selv er herre over det evige dvs. når dette ikke er reduceret til menneskets egen spekulation men i stedet tænkes som en virkelig eksisterende, almægtig gud - så er mennesket også i dette valg bundet til det evige, dvs. så kan det kun sige enten ja eller nej til den almægtige guds vilje: nødvendigheden sejrer over vilkårligheden. Denne tænkemåde bliver $\mathrm{i}$ en deterministisk filosoferende tid så at sige den eneste mulige for det religiøse menneske, og for den kristne bliver det særlig vanskeligt, fordi kristendommen lærer, at Gud har åbenbaret sig $\mathrm{i}$ et menneske, der levede og døde for henved 2000 år siden. Kravet bliver ifl. Kierkegaard ensbetydende med - ikke blot spekulerende og historielæsende, men inderligt følende og eksisterende - at være samtidig med Jesus, som om man levede og tog stilling til ham i samme øjeblik. - Dette er ikke blot et absurd krav til den tænkende, men også et uforståeligt krav til den ikke-tænkende menigmand - til de enfoldige, som Jesus særlig henvendte sig til og priste salige. - Hvor konsekvent Kierkegaards svar på samtidens tidsopfattelse end er, synes den altså at gøre kristendommen umulig for menigmand og lærde p.g.a. tidsopfattelsen. 
Når Kierkegaard forkastede Grundtvigs tidsopfattelse, var det, fordi han både fandt den forældet og ubrugelig for sig selv og samtidens tænkende mennesker. Han havde nok en vis respekt for Grundtvig som person, men kun hån tilovers for hans historieopfattelse, hvilket beror på, at Grundtvig havde forkastet den tidsopfattelse, Kierkegaard havde akcepteret. - De tænkte i forskellige tids-kategorier.

- Hvilken tænkemåde havde nu Grundtvig at sætte i stedet for Kierkegaards (og Hegels og Kants)?

Det ejendommelige ved Grundtvigs tænkemåde er, at han tager Bibelens tanker og forestillinger for fuldt alvor - ikke blot som billedlige, mytiske udtryk for virkelige, historiske forhold, men som de sandeste og nøjagtigste udtryk, han kender, for ting, hvorom vi ellers ingen viden har. Ordet "Aabenbaring“ betegner hos Grundtvig en direkte, guddommelig oplysning om forhold, vi ikke kan vide noget om, og som det ifølge Grundtvig ikke blot er ørkesløst men direkte vildledende at spekulere over. Vi kan ikke af os selv vide, hvordan eller hvorfor verden er blevet til, hvor længe den vil blive ved at bestå, hvordan dens skaber er, og om der er nogen hensigt med skabelsen af verden og os. Vi véd kun, at vi er blevet til, og at verden er blevet til; det er og bliver gådefuldt, hvordan de første mennesker og verden i dens første tilstand er blevet til. 1. Mosebog indeholder et svar på disse gåder, som Grundtvig forholder sig til med religiøs ærefrygt. - At verden ikke er blevet til af sig selv, og at vi mennesker ikke er blevet til af os selv, forekommer ham en given ting. Han gjorde aldrig nogen forsøg på at omgå skabelsestanken. Den påstand, at verden og vi mennesker ikke var skabt, men så at sige havde skabt os selv - ja, at vi endog havde skabt vor egen skaber - forekom Grundtvig simpelthen løgn. Alt må have en årsag, og mennesket (menneskene) kan ikke være sin (deres) egen årsag. Noget kan ikke have intet til årsag. - Men bortset fra denne ifølge Grundtvig uomgængelige kendsgerning, er 1. Mosebogs skabelses- og syndefaldsberetning en åbenbaring, som vi må tro, fordi vi ingen bedre har. - Andre folk har andre forestillinger, myter, som de forholder sig lige så troende til. Men vor tro hænger sammen med de forestillinger, 1. Mosebog har „åbenbaret“ os ved en guddommelig, digterisk inspiration.

Hvis man ikke går ind på denne tænkemåde, forstår man ikke 
Grundtvig. - Det væsentlige er, at han forkaster samtidens forkastelse af skabelsestanken. Men dermed er også opfattelsen af tiden som begrænset given. Tidens ende, dommedag, er også hentet fra Bibelen, nemlig fra Jesu ord i Det nye Testamente, fx. i Matth. 25, eller fra indledningen til Efeserbrevet. -

Grundtvig afstår således fra at gøre en spekulativ idealistisk betragtning til grundlaget for sin tænkning. Han vælger i stedet at gøre den bibelske skabelsesmyte til genstand for sin tro, til åbenbaring. Og de tanker og forestillinger, Grundtvig i modsætning til Luther indlader sig på, om den treenige Gud og det nyskabte menneske, går alle ud fra skabelsestanken: verdens tid er begrænset, lige såvel som det enkelte menneskes levetid, mennesket og verden må være afhængige af noget andet, som ikke er begrænset, og som har ubegrænset, evigt liv. Fra den begrænsede tid og det begrænsede liv slutter han til en ubegrænset tid og et ubegrænset liv. - Dette fundament er for Grundtvig hverken nogen fantasi eller nogen myte, men en grundsætning: Noget må vare årsag til noget. At vi så ikke er i stand til at iagttage, men kun kan gøre os billedlige forestillinger om det oprindelige noget, skyldes den faktisk eksisterende grænse for vor viden. I denne situation er billedlige forestillinger $\mathrm{i}$ og for sig naturlige at gribe til; men 2 . Mosebog har direkte forbudt at danne sig noget billede at sætte i skaberens sted: Gud er usynlig. Her går grænsen for vor viden. $\mathrm{Og}$ en spekulativ påstand er som fundament ikke bedre end opstillingen af gudebilleder $i$ hedenske templer.

For Grundtvig bevæger tid og evighed sig altså ad én linie $\mathbf{i}$ samme retning, blot med den forskel, at linien for Skaberen er ubegrænset, men for det skabte begrænset.

Hvad der gør Grundtvigs tids- (og historie-)opfattelse kompliceret er derfor ikke evighedsbegrebet, men syndefaldet. $\mathrm{Og}$ syndefaldet er hverken den materielle verdens tilblivelse eller puberteten (som i så mange moderne fortolkninger af 1. Mosebog, allerede Kants og Schellings, men også Kierkegaards i Begrebet Angest), men simpelthen menneskets afvigelse fra Guds bestemmelse med menneskets udvikling $i$ tiden. Man kan kalde det ulydighed; Grundtvig bruger i stedet den simple sætning: mennesket faldt ved at misbruge sin fornuft - ved at tro sig klogere end Gud.

Ifølge Grundtvig var det altså muligt for mennesket at afvige 
fra den vej, skaberen havde udpeget for det, dvs. det havde en fri vilje. Det havde mulighed for at være ulydig, for at misbruge sin fornuft med døden til følge, frelse senere. Den endimensionale tid blev i Grundtvigs forestillingsverden "fladet ud" til en strøm, bestående af flere forskellige vanddrag, der dog alle bevægede sig i samme retning. Dette er det billede, Grundtvig har overtaget fra tyskeren Fr. Strass: „Strom der Zeit", og under dette billede har Grundtvig ligefrem udgivet et tegnet tidskort: „Tidens Strøm“ som illustration til sin korteste fremstilling af verdenshistorien („Hist. Børne-Lærdom“ 1827). - Når alle disse vanddrag bevægede sig $i$ samme retning, skyldes det ifl. Grundtvig, at tiden og Gud er stærkere end det enkelte menneske og de grupper af mennesker, der former menneskenes historie. „I tænkte ondt imod mig, men Gud tænkte at vende det til det gode, for at gøre, hvad nu er sket og holde mange mennesker i live," som Josef sagde til sine brødre efter Jakobs død - i slutningen af 1. Mosebog. Hermed er grundtanken i Grundtvigs historiesyn klart udtrykt og altså hentet fra Bibelen.

Det er tiden og Guds almagt, der gør, at mennesket ikke kan forandre den retning, i hvilken bevægelsen går, kun foretage afvigelser derfra, beroende på den frie vilje, hvormed mennesket er skabt, dvs. de muligheder - større eller mindre, - ethvert menneske altid har for at vælge en anden vej end den, som dels naturnødvendigheden udpeger, dels den følelse af Guds vilje, hvormed mennesket er udstyret, men som det ikke er tvunget til at følge. - Det er disse afvigelser, der gør historien uberegnelig, spændende - men som også kan fore til en katastrofe, ikke blot det enkelte menneskes, men til menneskehedens $d ø d$ - hvorefter ethvert menneskes dom følger. Også den er uberegnelig, jf. lignelserne i Math. 25: der dømmes ikke blot efter lydighed eller ulydighed imod en uberegnelig herre, men efter kærligheden til medmennesket, der altid repræsenterer Gud. 